\title{
1. Lay conceptions of emotion in law
}

\author{
Terry A. Maroney
}

Perhaps the most common lay perception of emotion in law is that the former has no place in the latter. As many other contributions to this volume no doubt will explain, traditional legal scripts posit that reason and emotion are different beasts entirely: they belong to separate spheres of human existence; the sphere of law admits only of reason; and vigilant policing is required to keep emotion from creeping in where it does not belong. ${ }^{1}$ Those other contributions no doubt also will go on to explain the myriad reasons why such scripts are deeply flawed.

One of those reasons is that the proper resolution of many legal questions relies on perception and assessment of the presence, content, function, and impact of emotional states. For example, we sometimes decline to admit relevant evidence because we fear that the emotions it will provoke may unnecessarily traumatize and distract jurors; we consider anger and jealousy in determining whether to treat a killing as manslaughter; we determine the legality of government conduct by asking whether it is sufficiently shocking; we measure levels of emotional distress in setting tort damages. When faced with questions to which emotional phenomena are critical, legal decision makers tend to rely on their own, implicitly held concepts of those phenomena. Such "emotional common sense" is what one thinks she simply knows about emotions, based on personal experience, socialization, and other forms of casual empiricism. Like other forms of common sense, it is a form of unreflective knowledge, cultivated in the laboratory of life and experienced by the holder as simple truth. ${ }^{2}$

To no small degree, emotional common sense is unavoidable. A great many legal judgments are based on common sense judgments about the world ${ }^{3}$ - indeed, common sense is among the most frequently cited authorities for legal argument. ${ }^{4}$ What is distinctive about emotional common sense is that many people, legal decision makers included, are likely to believe that folk wisdom is the only sort of wisdom to be had about emotions. Legal decision makers may apply their own concepts of physics when imagining how a car accident likely occurred, but

1 Terry A. Maroney, "Law and Emotion: A Proposed Taxonomy of an Emerging Field," Law and Human Behavior 30, no. 2 (2006): 119-42.

2 Terry A. Maroney, "Emotional Common Sense as Constitutional Law," Vanderbilt Law Review 62, no. 3 (2009): 851-916, accessed May 23, 2019, https://heinonline.org/HOL/P?h=hein.journals/ vanlr62\& $\mathrm{i}=855$.

3 Richard E. Redding, "How Common-Sense Psychology Can Inform Law and Psycholegal Research," University of Chicago Law School Roundtable 5, no. 1 (1998): 107-42, accessed May 23, 2019, https://chicagounbound.uchicago.edu/roundtable/vol5/iss1/6; Richard H. Thompson, "Common Sense and Fact-Finding: Cultural Reason in Judicial Decisions," Legal Studies Forum 19, no. 2 (1995): 119-38, accessed May 23, 2019, https://heinonline.org/HOL/P?h=hein.journals/lstf19\&i=129; David E. Van Zandt, "Common sense Reasoning, Social Change, and the Law," Northwestern University Law Review 81, no. 4 (1987): 894-940, accessed May 23, 2019, https://heinonline.org/HOL/P?h=hein .journals/illlr81\&i=904.

4 Ronald J. Allen, "Common Sense, Rationality, and the Legal Process," Cardozo Law Review 22 (2001): 1417-31, accessed May 23, 2019, https://heinonline.org/HOL/P?h=hein.journals/cdozo22\&i= 1441. 
they almost certainly are aware that the movement of objects through space is the subject of an area of scientific inquiry; further, they often will realize that their knowledge is inadequate to answer complex questions. The same cannot be assumed about emotion-relevant questions, which may seem uniquely suited to lay assessment. ${ }^{5}$ As Descartes wrote, because "every one has experience of the passions within himself, there is no necessity to borrow one's observations from elsewhere in order to discover their nature."

Emotion-relevant legal questions, then, often fall into an epistemological blank space. This is an unacceptable state of affairs. It is unacceptable, first, because it destabilizes law: when the bases upon which law is made are idiosyncratic, so too is the law itself. This state of affairs also is unacceptable because, in many instances, stable bases for emotional assessment exist. Finally, where no such bases exist, emotional assessment should be openly acknowledged as an expression of one's beliefs and values, not passed off as simple truth.

The 2006 U.S Supreme Court case Carey v. Musladin ${ }^{7}$ nicely demonstrates the costs of relying so heavily on lay concepts of emotion. The Court sought to determine the permissibility of allowing family members of the deceased to wear buttons showing his face while attending the murder trial of the man accused of killing him. At oral argument, several Justices opined that a typical juror would see the buttons as an innocuous sign of "normal grief," and that they therefore were permissible; one believed they communicated simply that the deceased was loved and missed, and on that basis were permissible; another saw the buttons' legality hinging on whether the family was doing what people "naturally do" when grieving, as opposed to "going out of their way to do something that people in mourning do not normally do." Amicus parties were of no help, as they saw the buttons as conveying directly opposing messages, both of which they characterized as "obvious" and "commonsensical." "The Court appeared to have no concept of how it should resolve the competing claims as to the buttons' emotional meaning and impact; nor did it appear to have any principled mechanism for discerning the legal relevance of such meaning and impact. Finding itself radically unmoored, the Court punted. This area of the law remains without coherent guidance. The same is true of particularly emotionally saturated types of victim impact evidence, such as victim tribute videos. ${ }^{9}$ Indeed, a number of lower courts continue to complain about this lack of guidance, which renders this area of law hopelessly idiosyncratic. ${ }^{10}$

The many areas of law that depend on emotional assessment should be understood as an epistemologically rich space, not a blank one. Invocations of emotional common sense belong in that space but they should not wholly occupy it, as they sometimes are accurate, some-

5 Gerald L. Clore, and Karen Gasper, "Feeling Is Believing: Some Affective Influences on Belief," in Emotions and Beliefs: How Feelings Influence Thoughts, eds. Nico H. Frijda, Anthony S.R. Manstead, and Sacha Bem (Cambridge: Cambridge University Press, 2000), 10-44.

6 Cheshire Calhoun, and Robert C. Solomon, eds., "René Descartes: From The Passions of the Soul," in What Is an Emotion? Classic Readings in Philosophical Psychology (New York: Oxford University Press, 1984), 55.

7 Carey v. Musladin, 549 U.S. 70, 72-73 (2006).

8 Brief of the National Ass'n of Criminal Defense Lawyers at 9, as Amicus Curiae Supporting Respondent, Carey v. Musladin, 549 U.S. 70 (2006) (No. 05-785); Brief of the New Jersey Crime Victims' Law Center at 3, 11, as Amicus Curiae Supporting Petitioner, Carey v. Musladin, 549 U.S. 70 (2006) (No. 05-785).

9 Kelly v. California, 129 S. Ct. 564, 564 (2008).

10 Storey v. Roper, 603 F.3d 507, 529 (8th Cir. 2010); Anker v. Wesley, 789 F. Supp. 2d 487, 501 (D. Del. 2011). 
times are not, and always reflect one's worldview. ${ }^{11}$ This brief chapter uses decisions of the United States Supreme Court to illustrate these points, not because that is the most important court - far from it — but rather because the Court has never displayed any sustained inclination to regard emotions with anything other than a lay perspective. It therefore regularly provides illustrative, high-profile instances from which to learn.

\section{THE INTERMITTENT ACCURACY OF LAY CONCEPTS OF EMOTION IN LAW}

Sometimes common sense and the weight of reliable external data will concur, a "delightfully harmonious situation." 12 Lay concepts of emotion are empirical, though casually so, in that they are based on human observation and experience, accumulated and passed on over time. Thus, emotional common sense will embody certain truths. For example, the common notion that emotions are involuntary, quick, and can temporarily displace other mental operations is generally true with regard to a small set of evolutionarily basic emotions, such as fear. ${ }^{13}$ It also is largely true that - as most people believe-feelings of fear both reflect and communicate vital information about danger. ${ }^{14}$ Therefore, emotional common sense sometimes ought to be respected as a useful synthesis of collective observation about the domain with which humans are most familiar: our everyday emotional lives. To the extent that it imports into law such stable insights, its use is either innocuous or positive. Certainly to the extent that the legal system deliberately assigns certain decision making to lay participants, such as jurors, lay conclusions about emotional phenomena should be presumptively proper to the extent that they are proper as to other sorts of phenomena. Laypersons are not experts in physics either, but they are perfectly good judges of how ordinary objects tend to move through space in ordinary conditions, such as those they encounter in their daily lives.

The Supreme Court's decision in Cohen v. California (1971) provides an example of an instance in which the Justices' emotional common sense was both well-founded and unlikely to have been meaningfully shifted by additional, external sources of knowledge. ${ }^{15}$ Cohen was charged with disorderly conduct after wearing a jacket bearing the words "Fuck the Draft" in protest of the Vietnam War. The Court recognized that the government could not penalize his expression of opposition to the war. In deciding that the government further could not penalize the vulgar way in which he expressed that opposition, it relied heavily on its belief that particular words convey not only ideas, "but otherwise inexpressible emotions as well. In fact, words are often chosen as much for their emotive as their cognitive force." 16 The Constitution, the Cohen Court decided, protects the "emotive function" of speech as much as the literal words

\footnotetext{
11 Maroney, "Emotional Common Sense."

12 Paul E. Meehl, "Law and the Fireside Inductions: Some Reflections of a Clinical Psychologist," Journal of Social Issues 27, no. 4 (1971): 95, https://doi.org/10.1111/j.1540-4560.1971.tb00679.x.

13 Joseph E. LeDoux, The Emotional Brain: The Mysterious Underpinnings of Emotional Life (New York: Simon \& Schuster, 1996).

14 Arne Öhman, "Fear," in Oxford Companion to Emotion and the Affective Sciences, eds. Klaus R. Scherer and David Sander (New York: Oxford University Press, 2009), 182-3.

15 Cohen v. California, 403 U.S. 15 (1971).

16 Cohen v. California, 403 U.S. at 26.
} 
themselves. The word "fuck" necessarily conveyed that emotional message and could not be regulated "without effectively repressing Cohen's ability to express himself."

It is notable that the Cohen majority simply invoked its own views about the relationship between emotion and speech, reflecting an implicit judgment that some words and language patterns are more emotionally salient than others, emotional speech conveys information, and emotional speech conveys different information than does less emotionally salient speech. As it turns out, these ideas are generally quite true, supported by the organized research literature as well as by the Justices' casual empiricism. ${ }^{17}$ Further, the determination by the Cohen Court sits at a high level of abstraction (do particular words convey emotion?); is embedded in an ordinary setting (seeing a person wearing a jacket on the street); directly implicates the generalized experience of the community (do people understand that the word "fuck" signals emotional intensity?); and is easy to plug into a pre-existing legal rubric (if the particular mode of expression is directly informational, it cannot be criminalized). These parameters provide guidance as to the situations in which lay assessment of emotion is most likely to be unobjectionable, even salutary, in law.

These parameters, however, must remain tight. Often a judgment that appears amenable to lay assessment actually is not, and legal decision makers are likely to misjudge the number of cases that fit into the Cohen category.

Consider the case of Safford v. Redding (2009), which declared unconstitutional the strip search of a young teenage girl by school officials searching for evidence of unauthorized possession of prescription strength Advil. ${ }^{18}$ A key issue in that case was the level of humiliation, shame, and emotional distress a girl in Redding's position would feel during such a search. At first glance this appears to be at the Cohen level of simplicity; every adult judge or juror has been a child, and presumably has had direct experience dealing with school officials. Though they likely have not had this precise experience, they should be able to imagine how they would have felt if they had. The empathic leap, however, represents a problem. During oral argument, it became clear that one of the male Justices was having trouble imagining why this search (which involved the girl momentarily exposing her breasts to adults) could be traumatic; instead, he brought to bear his own perspective of having been a boy in locker rooms with other boys. ${ }^{19}$ He was promptly schooled by a female Justice - Ruth Bader Ginsburgwho, speaking from her more particular experience with having been a teenage girl, expressed a strong view that of course it was traumatic. ${ }^{20}$

17 Margaret M. Bradley, and Peter J. Lang, "Affective Norms for English Words (ANEW): Instruction Manual and Affective Ratings," Technical Report C-1 (Gainesville, 1999), accessed May 23, 2019, http://citeseerx.ist.psu.edu/viewdoc/download?doi=10.1.1.306.3881\&rep=rep1\&type=pdf; Zoltán Kövecses, "Introduction: Language and Emotion Concepts," in Everyday Conceptions of Emotion: An Introduction to the Psychology, Anthropology and Linguistics of Emotion, James A. Russell, José-Miguel Fernández-Dols, Anthony S.R. Manstead, and J.C. Wellenkamp, eds. (New York City: Springer, 1995), 3-15; Tom Johnstone and Klaus R. Scherer, "Vocal Communication of Emotion," in Handbook of Emotions (2d ed.), Michael Lewis and Jeannette M. Haviland-Jones, eds. (New York: Guilford Press, 2004), 220-35.

${ }_{18}$ Safford Unified School District v. Redding, 557 U.S. 364 (2009). 133-148.

19 Susan Bandes, Empathetic Judging and the Rule of Law," Cardozo Law Review De Novo (2009):

20 Adam Liptak, "Supreme Court Says Child's Rights Violated by Strip Search," New York Times, June 25, 2009, accessed May 23, 2019, https://archive.nytimes.com/www.nytimes.com/2009/06/26/us/ politics/26scotus.html. 
Justice Ginsburg's perspective won the day. One can imagine, though, that if there were no women in positions of decisional power this case might have been decided otherwise. Emotional experiences are not universal, but rather are grounded in and reflective of variables such as culture, age, gender, race, and power status. ${ }^{21}$ Particularly because legal decision makers seldom, if ever, perfectly reflect the diversity of any given community, importing their lay assessments into law poses a significant danger. Those decision makers may project themselves into a scenario, imagine how they think they would feel, and assume that dissimilar others would feel the same. Not only may they be wrong in imagining their own affective states, they may be even more wrong in imagining those of others. ${ }^{22}$ Folk wisdom, already on shaky ground, is even shakier when those invoking it are not even part of the affected "folk."

Finally, sometimes emotional common sense is simply incorrect, not just as to certain other people but as to all people. For example, the U.S. Supreme Court's decision upholding the criminalization of a particular abortion procedure in Gonzalez v. Carhart ${ }^{23}$-more on that case in a moment-reflects a number of lay psychological assumptions about regret that fundamentally miss the mark. The Carhart majority failed to take account of regret aversion (that is, the reality that people commonly factor their desire to avoid later regrets into their decision making), overestimation (in doing so, people tend to inflate the imagined regret's intensity and duration), dampening (if we do experience regret, we tend to deploy psychological tools to manage it), and learning (our regrets can strengthen future decision making). It "got regret wrong," resting a highly disputed decision on a deeply misguided foundation. ${ }^{24}$

On a broader level, this category encompasses the many ways in which legal doctrine incorporates the supposition that emotion and reason are oppositional forces and that emotion by its nature distorts and displaces the legal reasoning on which the rule of law depends. No doubt the other entries in this volume will thoroughly catalogue those instances. One need look no further than the words of Thomas Hobbes in Leviathan, in which he declared that a good judge is one who is free of all hatred, fear, love, and compassion, ${ }^{25}$ while in fact good judges need a high level of awareness of and facility with their emotions in order to perform critical aspects of their jobs. ${ }^{26}$ Similarly, courts in the United States frequently instruct jurors to set

${ }^{21}$ Kathryn J. Lively, “The Sociology of Emotion,” in Handbook of Emotions (4th ed.), Lisa Feldman Barrett, Michael Lewis, and Jeannette M. Haviland-Jones, eds. (New York: Guilford Press, 2018), 66-81; Leslie R. Brody, Judith A. Hall, and Lynissa R. Stokes, "Gender and Emotion: Theory, Findings, and Context," in Barrett et al., Handbook of Emotions, 369-92; Batja Mesquita, Jozefien De Leersnyder, and Michael Boiger, "The Cultural Psychology of Emotions," in Barrett et al., Handbook of Emotions, 393-411; Amy S. Wharton, "The Sociology of Emotional Labor," Annual Review of Sociology 35 (2009): 147-65, accessed May 23, 2019, https://doi.org/10.1146/annurev-soc-070308-115944.

22 Jeremy A. Blumenthal, "Law and the Emotions: The Problems of Affective Forecasting." Indiana Law Journal 80 (2005): 155-238.

23 Gonzales v. Carhart, 550 U.S. 124 (2007).

24 Chris Guthrie, "Carhart, Constitutional Rights, and the Psychology of Regret," Southern California Law Review 81, no. 5 (2008): 882, accessed May 23, 2019, https://southerncalifornialawreview.com/wp -content/uploads/2018/01/81_877.pdf.

${ }_{25}$ Thomas Hobbes, Leviathan (Cambridge University Press, 1904).

26 Terry A. Maroney, "The Persistent Cultural Script of Judicial Dispassion," University of California Law Review 99, no. 2 (2011): 629-82, accessed May 23, 2019, https://doi.org/10.15779/ Z38K98M; Terry A. Maroney, "Emotional Regulation and Judicial Behavior," University of California Law Review 99, no. 6 (2011): 1485-556, accessed May 23, 2019, https://doi.org/10.15779/Z38XQ3J; Sharyn Roach Anleu, and Kathy Mack, "Magistrates' Everyday Work and Emotional Labour," Journal of Law and Society 32, no. 4 (2005): 590-614; Sharyn Roach Anleu, and Kathy Mack, Performing 
their emotions aside when reaching their decisions, instructions that rest on the supposition that "passions" are by their nature untethered to relevant evidentiary or moral considerations and therefore will lead them astray. ${ }^{27}$ These suppositions are deeply wrong on multiple levels: they ignore the facts that emotions are tethered to information, that moral judgments necessarily implicate the emotions, and that resolution of important issues may require that the jurors consult their emotions (for instance, to determine whether a defendant's behavior was especially shocking and cruel). ${ }^{28}$

Thus, lay beliefs about and assessments of emotion sometimes are perfectly appropriate, though the parameters within which that is true are limited. Sometimes those lay beliefs and assessments may be true for the decision maker but not for others, in a way that will not be obvious to the decision maker him or herself. Sometimes such views are against the weight of empirical evidence, though they may be in line with widespread belief.

\section{LAY CONCEPTS OF EMOTION IN LAW REFLECT ONE'S WORLDVIEW}

Accuracy is only one rubric by which to measure the propriety of emotional common sense in law. Not all emotional common sense can be characterized as "correct" or not. In a great many instances, there are "competing correct" versions of reality at play. In these cases, the question is not so much whether a legal decision maker has made a "right" or "wrong" assessment, but rather the extent to which the assessment may be both instrumental and value-laden.

First, legal decision makers are likely to interpret relevant emotional phenomena in a manner that comports with their desired normative ends. In Weeks $v$. Angelone,${ }^{29}$ the Justices differed sharply in their interpretation of tears that had been shed by members of a capital sentencing jury when announcing their verdict of death. The legal issue was whether the jury instruction improperly had suggested that those jurors had a duty, rather than an option, to impose death upon proof of a statutory aggravator. Justice Stevens interpreted the jurors' tears as evidence that they believed they had a duty, did not want to comply with that duty, and were crying out of frustration. Chief Justice Rehnquist, in contrast, thought it just as plausible "that jurors were in tears because they had just been through an exhausting, soul-searching process" ending in their voluntary decision to impose the death penalty. Here we see two different common-sense views about the triggers for, function of, and information conveyed by crying. In the first, crying is something people do when trapped in an intolerable situation. In the second, crying is something people do when exhausted and drained. Both propositions are plausible and well supported in the academic literature,$^{30}$ and both appear commonsensical. In different

Judicial Authority in the Lower Courts (London, UK: Palgrave Macmillan, 2017); Stina Bergman Blix, and Åsa Wettergren, Professional Emotions in Court: A Sociological Perspective (London, UK: Routledge, 2018).

27 California v. Brown, 479 U.S. 538 (1987); Saffle v. Parks, 494 U.S. 484 (1990).

28 Terry A. Maroney, "Emotional Common Sense."

29 Weeks v. Angelone, 528 U.S. 225 (2000).

30 Ad Vingerhoets, and Lauren Bylsma, "Crying as a Multifaceted Health Psychology Conceptualisation: Crying as Coping, Risk Factor, and Symptom," The European Health Psychologist 9 (2007): 68-74, accessed May 23, 2019, https://www.researchgate.net/profile/Lauren_Bylsma/ publication/230794262_Crying_as_a_multifaceted_health_psychology_conceptualisation_crying 
circumstances, either Justice would regard the other's assertion is eminently obvious. Which interpretation seems obvious in a given instance has to do with the prior assessment as to the attributes of that instance. Is this case one in which the death penalty was appropriate, or is it not? What position does the Justice see himself as occupying: the juror who wants to spare the defendant's life, or the one who does not?

In such a situation, assertions of emotional common sense are best understood as indicators of a person's underlying normative assessments, based on her worldview. Further evidence of this phenomenon pervades a long line of cases involving the legality of vociferous antiabortion protests outside of medical clinics. In these cases, Justices often reveal their worldview by displaying a strong empathic connection with one side. ${ }^{31}$ The empathic divisions lie along two general axes: the presumptive emotional impact of protest on abortion providers and patients, and the presumptive emotional motivation and communicative dynamic of the protester. ${ }^{32}$ Some Justices easily imagine that a woman seeking an abortion will experience fear and anxiety when confronted by an antiabortion protester, whom they assume will display both physical and verbal aggression. Other Justices instead imagine such a protester speaking in a quiet, compassionate voice, quietly approaching a woman seeking an abortion and gently moving her heart. These Justices are not construing different situations, mind you; they are differentially construing the emotional dynamics and content of the same situation. The manner in which they do so is driven by whom they relate to and how they think the world works.

To be sure, this phenomenon is not limited to emotion generally or to empathy specifically; it is a close cousin of the "cultural cognition" documented by Kahan and his collaborators. ${ }^{33}$ People often filter evidence through their worldview, and are more willing to accept evidence when it conforms to their commitments and to challenge it when it does not. ${ }^{34}$ But it is important to note just how thoroughly these troublesome phenomena instantiate when the thing being judged is emotion. Emotional common sense is so relatively invisible, so likely to be regarded by so many as "just so," that it is particularly unlikely to be interrogated. Especially when legal decision makers are members of elites or otherwise culturally powerful subgroups, invocation of emotional common sense may silently privilege their views.

as_coping_risk_factor_and_symptom/links/0fcfd50479cf7a098e000000.pdf; Daniel M.T. Fessler, and Cristina M. Moya, "Crying (Evolutionary Perspectives)," in Oxford Companion to Emotion and the Affective Sciences, Klaus Scherer and David Sander, eds, (New York: Oxford University Press, 2009) $105-6$.

${ }_{31}$ Terry A. Maroney, "Emotional Common Sense"; Dan M. Kahan, David A. Hoffman, Donald Braman, Danieli Evans, and Jeffrey J. Rachlinski, “'They Saw a Protest': Cognitive Illiberalism and the Speech-Conduct Distinction," Stanford Law Review 64, no. 4 (2012): 851-906, accessed May 23, 2019, http://www.stanfordlawreview.org/wp-content/uploads/sites/3/2012/05/Kahan-64-Stan-L-Rev-851.pdf.

32 Madsen v. Women's Health Center, Inc., 512 U.S. 753 (1994); Hill v. Colorado, 530 U.S. 703 (1997).

33 Dan M. Kahan, "Culture, Cognition, and Consent: Who Perceives What, and Why, in Acquaintance-Rape Cases," University of Pennsylvania Law Review 158, no. 3 (2010): 729-813, accessed May 23, 2019, https://scholarship.law.upenn.edu/cgi/viewcontent.cgi?article=1137\&context= penn_law_review.

${ }^{34}$ Dan M. Kahan, David A. Hoffman, and Donald Braman, "Whose Eyes Are You Going to Believe? Scott v. Harris and the Perils of Cognitive Illiberalism," Harvard Law Review 122, no. 3 (2009): 837-906, accessed May 23, 2019, http://harvardlawreview.org/wp-content/uploads/2009/04/ kahan_hoffman_braman.pdf. 
Finally, we return to Gonzales v. Carhart, ${ }^{35}$ in which the Court upheld the federal Partial-Birth Abortion Ban Act of 2003. As an initial matter, it is worth noting that this case presented the same danger noted in Safford $v$. Redding, ${ }^{36}$ but with a different outcome. As Justice Ginsburg points out in her Carhart dissent, the only people to whom the majority's lay emotional judgments could apply are women, and every member of the majority was a man. At an even deeper level, Carhart vividly manifests the way in which emotional common sense often conflates the "is" with the "ought," or elides the difference between the two, reflecting a seemingly "natural morality" that reveals underlying belief structures and value judgments. ${ }^{37}$

Justice Kennedy's majority opinion is chock-full of lay assertions about love, regret, grief, and sorrow. He wrote that "[r]espect for human life finds an ultimate expression in the bond of love the mother has for her child," and that while the Court found "no reliable data to measure the phenomenon, it seems unexceptionable to conclude some women come to regret their choice to abort the infant life they once created and sustained" and that "[s]evere depression and loss of esteem can follow." 38 Kennedy continued:

It is self-evident that a mother who comes to regret her choice to abort must struggle with grief more anguished and sorrow more profound when she learns, only after the event, what she once did not know: that she allowed a doctor to pierce the skull and vacuum the fast-developing brain of her unborn child, a child assuming the human form.

Justice Kennedy's views on these complicated emotional phenomena are proudly folk-psychological, claimed to be so obvious as to require no data outside of what appears to him to be self-evident. The notion that such observations can and should drive critical legal determinations is, apparently, even more self-evident, as it receives no mention at all.

At the heart of Kennedy's assessment are his assumptions about post-abortion regret. Regret is a painful feeling, reflecting a person's negative self-evaluation based on voluntary action now judged to be an avoidable mistake, characterized by thoughts of opportunities lost, "kicking oneself," and desire to undo the decision if one could. ${ }^{39}$ Despite Kennedy's claims to the contrary, as Justice Ginsburg was quick to point out in her dissent, an enormous scientific literature examines post-abortion regret. The weight of that evidence indicates that while some women do regret abortion, just as many people regret many difficult life decisions, that regret seldom causes serious psychological damage; more, many women never regret the abortion at all, though they may regret the circumstances that made it appear necessary. Further, no data indicate that instances of psychologically-damaging regret are more common with this particular abortion procedure. Rather than engage with that scientific literature, Justice Kennedy relies on what he feels to be true - and on an amicus brief compiling first-person accounts from women who have come to regret their abortions. Those accounts are no doubt sincere, but they do not purport to examine regret among a representative sample of post-abortive women (let alone women who have had the specific procedure). Further, the women sharing their stories

Gonzales v. Carhart, 550 U.S. 124 (2007).

Safford Unified School District v. Redding, 557 U.S. 364 (2009).

Van Zandt, "Common Sense Reasoning," 916.

Gonzales v. Carhart, 550 U.S. 124, 159 (2007).

9 Guthrie, "Carhart, Constitutional Rights, and the Psychology of Regret"; Marcel Zeelenberg, "Regret," in Oxford Companion to Emotion and the Affective Sciences, Klaus R. Scherer and David Sander, eds (New York: Oxford University Press, 2009), 336. 
generally regret their abortions because of a very specific belief structure, the one also adopted by Operation Outcry, the amicus party: they have come to believe that they were "mothers," that their fetuses were "children," and therefore that they have committed "murder."

That, in a nutshell, is what Carhart boils down to. Justice Kennedy shares that belief structure, and fills in the emotional experiences that he believes should correspond to it. When he valorizes the "bond of love the mother has for her child," he is not so much stating a fact - that all mothers love their children - as declaring a value: all mothers should love their children. When he attaches that value to the relationship between a pregnant woman and fetus, he is declaring that the former is a "mother" and the latter is a "child," and therefore the same emotional script should apply. When he says that women will regret abortion, he is declaring that women should regret abortion. Finally, when he goes on to say that women particularly will regret a "partial-birth abortion" because it is (in his view) gruesome, he is declaring that women should find the procedure disgusting and, therefore, intolerable.

In short, Justice Kennedy's logic runs as follows: a woman who aborts destroys the profound bond of love she had, and would have continued to have, with her child; once she realizes this, she will see that her choice to abort was an avoidable mistake; she accordingly will suffer regret; that regret will be even more acute if she realizes the gruesome manner in which she chose to kill her child; and crippling regret is so likely to damage so many womenbecause most women are normal, decent human beings who will feel this way once they see the truth - as to justify banning the procedure altogether, to save them from this inevitable emotional harm.

This expression of emotional common sense positively bristles with culturally specific, morally contested judgments - the very judgments on which the Constitution is meant to remain agnostic, according to Roe and its progeny - and forces a false consensus on them. The Carhart Court has taken sides while pretending to be stating nothing more than common sense about basic emotional reality among decent, right-thinking people.

\section{LAY CONCEPTS OF EMOTION IN LAW SHOULD BE INTERROGATED}

Emotional common sense, as this brief discussion has shown, is a highly complex phenomenon dressed up as a simple one. It represents one way in which legal decision makers may pass contentious judgments of value on by passing them off as uncontestable matters of fact. But emotional common sense is of uneven epistemological value. It is prone to instrumental use. It influences how legal decision makers perceive relevant facts and law, and provides a fig leaf under which to obscure contested views of social justice and the good life. It is largely invisible to its holder, but absurd to one whose common sense lies elsewhere.

Emotional common sense may be cautiously embraced - or at least tolerated - where the legal determination involves extremely basic emotions as manifested in everyday settings, for in that instance emotional common sense may be so likely to be accurate as to be an acceptable source. The (limited) embrace should be largely withheld, though, where the legal decision maker is asked to evaluate complex emotions, particularly those of other people. In these situations, the inaccuracy, instrumentalism, and parochialism to which all common sense is vulnerable are most likely to be at play. Legal decision makers are likely to overestimate vastly 
the instances in which their lay assessment is sufficient, and to fail to notice the extent to which their assessments embody contestable value judgments and overlook diverse perspectives.

The robust field of law and emotion, so well represented in this volume, seeks largely to educate scholars and legal decision makers about appropriately complex perspectives on the emotional questions that permeate law. Over time, lay assessment of emotion should become progressively more confined to those legal questions to which it is most appropriate. However, this is not a foregone conclusion. We will get there only by consistently and rigorously identifying and interrogating emotional common sense and law. All of us in the legal community, both scholars and decision makers, must take a more catholic view toward the sources of information about emotions, and a more humble view toward the universality of our own.

\section{REFERENCES}

Allen, Ronald J. "Common Sense, Rationality, and the Legal Process." Cardozo Law Review 22 (2001): 1417-31. https://heinonline.org/HOL/P?h=hein.journals/cdozo22\&i=1441.

Bandes, Susan A. "Empathetic Judging and the Rule of Law." Cardozo Law Review De Novo (2009): 133-48.

Bergman Blix, Stina, and Åsa Wettergren. Professional Emotions in Court: A Sociological Perspective. London: Routledge, 2018.

Blumenthal, Jeremy A. "Law and the Emotions: The Problems of Affective Forecasting." Indiana Law Journal 80 (2005): 155-238.

Bradley, Margaret M., and Peter J. Lang. "Affective Norms for English Words (ANEW): Instruction Manual and Affective Ratings." Technical Report C-1. Gainesville, 1999. http://citeseerx.ist.psu.edu/ viewdoc/download?doi=10.1.1.306.3881\&rep=rep1\&type=pdf.

Brody, Leslie R., Judith A. Hall, and Lynissa R. Stokes. "Gender and Emotion: Theory, Findings, and Context." In Handbook of Emotions (4th ed.), Lisa Feldman Barrett, Michael Lewis, and Jeannette M. Haviland-Jones, eds, 369-92. New York: Guilford Press, 2018.

Calhoun, Cheshire, and Robert C. Solomon, eds. "René Descartes: From The Passions of the Soul." In What Is an Emotion? Classic Readings in Philosophical Psychology, 55-70. New York: Oxford University Press, 1984.

Clore, Gerald L., and Karen Gasper. "Feeling Is Believing: Some Affective Influences on Belief." In Emotions and Beliefs: How Feelings Influence Thoughts, Nico H. Frijda, Anthony S.R. Manstead, and Sacha Bem, eds, 10-44. Cambridge: Cambridge University Press, 2000.

Fessler, Daniel M.T., and Cristina M. Moya. "Crying (Evolutionary Perspectives)." In Oxford Companion to Emotion and the Affective Sciences, Klaus Scherer and David Sander, eds, 105-6. New York: Oxford University Press, 2009.

Guthrie, Chris. "Carhart, Constitutional Rights, and the Psychology of Regret." Southern California Law Review 81, no. 5 (2008): 877-904. https://southerncalifornialawreview.com/wp-content/uploads/ 2018/01/81_877.pdf.

Hobbes, Thomas. Leviathan. Cambridge University Press, 1904.

Johnstone, Tom, and Klaus R. Scherer. "Vocal Communication of Emotion." In Handbook of Emotions (2d ed.), Michael Lewis and Jeannette M. Haviland-Jones, eds, New York: Guilford Press, 2004.

Kahan, Dan M. "Culture, Cognition, and Consent: Who Perceives What, and Why, in Acquaintance-Rape Cases." University of Pennsylvania Law Review 158, no. 3 (2010): 729-813. https://scholarship.law .upenn.edu/cgi/viewcontent.cgi?article=1137\&context=penn_law_review.

Kahan, Dan M., David A. Hoffman, and Donald Braman. "Whose Eyes Are You Going to Believe? Scott v. Harris and the Perils of Cognitive Illiberalism." Harvard Law Review 122, no. 3 (2009): 837-906. http://harvardlawreview.org/wp-content/uploads/2009/04/kahan_hoffman_braman.pdf.

Kahan, Dan M., David A. Hoffman, Donald Braman, Danieli Evans, and Jeffrey J. Rachlinski. “"They Saw a Protest': Cognitive Illiberalism and the Speech-Conduct Distinction." Stanford Law Review 
64, no. 4 (2012): 851-906. http://www.stanfordlawreview.org/wp-content/uploads/sites/3/2012/05/ Kahan-64-Stan-L-Rev-851.pdf.

Kövecses, Zoltán. "Introduction: Language and Emotion Concepts." In Everyday Conceptions of Emotion: An Introduction to the Psychology, Anthropology and Linguistics of Emotion, James A. Russell, José-Miguel Fernández-Dols, Anthony S.R. Manstead, and J.C. Wellenkamp, eds, 3-15. New York: Springer, 1995.

LeDoux, Joseph E. The Emotional Brain: The Mysterious Underpinnings of Emotional Life. New York: Simon \& Schuster, 1996.

Liptak, Adam. "Supreme Court Says Child's Rights Violated by Strip Search." New York Times (New York, NY), June 25, 2009. https://archive.nytimes.com/www.nytimes.com/2009/06/26/us/politics/ 26scotus.html.

Lively, Kathryn J. “The Sociology of Emotion.” In Handbook of Emotions ( $4^{\text {th }}$ ed.), Lisa Feldman Barrett, Michael Lewis, and Jeannette M. Haviland-Jones, eds, 66-81. New York: Guilford Press, 2018.

Maroney, Terry A. "Law and Emotion: A Proposed Taxonomy of an Emerging Field." Law and Human Behavior 30, no. 2 (2006): 119-42.

Maroney, Terry A. "Emotional Common Sense as Constitutional Law." Vanderbilt Law Review 62, no. 3 (2009): 851-916. https://heinonline.org/HOL/P?h=hein.journals/vanlr62\&i=855.

Maroney, Terry A. "Emotional Regulation and Judicial Behavior." University of California Law Review 99, no. 6 (2011): 1485-556. https://doi.org/10.15779/Z38XQ3J.

Maroney, Terry A. "The Persistent Cultural Script of Judicial Dispassion.” University of California Law Review 99, no. 2 (2011): 629-82. https://doi.org/10.15779/Z38K98M.

Meehl, Paul E. "Law and the Fireside Inductions: Some Reflections of a Clinical Psychologist." Journal of Social Issues 27, no. 4 (1971): 65-100. https://doi.org/10.1111/j.1540-4560.1971.tb00679.x.

Mesquita, Batja, Jozefien De Leersnyder, and Michael Boiger. "The Cultural Psychology of Emotions." In Handbook of Emotions (4th ed.), Lisa Feldman Barrett, Michael Lewis, and Jeannette M. Haviland-Jones, eds, 393-411. New York: Guilford Press, 2018.

Öhman, Arne. "Fear." In Oxford Companion to Emotion and the Affective Sciences, Klaus R. Scherer and David Sander, eds, 182-83. New York: Oxford University Press, 2009.

Redding, Richard E. "How Common-Sense Psychology Can Inform Law and Psycholegal Research." University of Chicago Law School Roundtable 5, no. 1 (1998): 107-42. https://chicagounbound .uchicago.edu/roundtable/vol5/iss1/6.

Roach Anleu, Sharyn, and Kathy Mack. "Magistrates' Everyday Work and Emotional Labour." Journal of Law and Society 32, no. 4 (2005): 590-614. https://doi.org/10.1111/j.1467-6478.2005.00339.x.

Roach Anleu, Sharyn, and Kathy Mack. Performing Judicial Authority in the Lower Courts. London, UK: Palgrave Macmillan, 2017.

Thompson, Richard H. "Common Sense and Fact-Finding: Cultural Reason in Judicial Decisions." Legal Studies Forum 19, no. 2 (1995): 119-37. https://heinonline.org/HOL/P?h=hein.journals/lstf19\&i=129.

Van Zandt, David E. "Common sense Reasoning, Social Change, and the Law." Northwestern University Law Review 81, no. 4 (1987): 894-940. https://heinonline.org/HOL/P?h=hein.journals/illlr81\&i=904.

Vingerhoets, Ad, and Lauren Bylsma. "Crying as a Multifaceted Health Psychology Conceptualisation: Crying as Coping, Risk Factor, and Symptom." The European Health Psychologist 9 (2007): 68-74.

Wharton, Amy S. "The Sociology of Emotional Labor." Annual Review of Sociology 35 (2009): 147-65. https://doi.org/10.1146/annurev-soc-070308-115944.

Zeelenberg, Marcel. "Regret." In Oxford Companion to Emotion and the Affective Sciences, edited by Klaus R. Scherer and David Sander, 336. New York: Oxford University Press, 2009. 